\title{
Islamic Law in Indonesia: Baḥtsul Masāil Ijtihad and the Production of Knowledge
}

\author{
Asrizal Saiin ${ }^{1.2}$, Abdul Kadir Jaelani ${ }^{3}$, Muhammad Jihadul Hayat ${ }^{4}$, Arifki Budia Warman ${ }^{5}$, Muhammad April $^{6}$ \\ ${ }^{1}$ STAIN Sultan Abdurrahman Kepulauan Riau, Indonesia \\ ${ }^{2}$ UIN Sulthan Thaha Saifuddin Jambi, Indonesia \\ ${ }^{3.4}$ Universitas Sebelas Maret Surakarta, Indonesia \\ ${ }^{5}$ IAIN Batusangkar Sumatera Barat, Indonesia \\ ${ }^{6}$ UIN Sultan Syarif Kasim Riau, Indonesia \\ asrizal@stainkepri.ac.id
}

\begin{abstract}
Indonesia is a state of law, while the majority of the population is Muslim. As a result of this circumstance, Islamic religious-based fatwa institutions are widespread. Numerous religious organizations have their own institutions managing fatwas on legal issues from both an Islamic and organizational perspective. Bahtsul Masāil is one of them. This institution is affiliated with Nahdlatul Ulama, Indonesia's most prominent Islamic community organization. The purpose of this paper is to examine how Baḥtsul Masāil manages Islamic law/fatwa and its intersection with the production of legal knowledge, which cannot be divorced from the organization's religious style. This article employs a portion of Foucault's genealogical critical discourse analysis approach. After conducting qualitative analysis, this article argues that whenever the Bahtsul Masāil considers a legal case, it always attempts to project its consideration to the four schools of Islamic law, namely the Shafi'i, Hanafi, Maliki, and Hambali schools. If the four schools are unable to resolve the legal issue, they move on to other schools or employ alternative reasoning with new considerations. Genealogically, this projection is a manifestation of the strong traditional authority in NU institutions. This is not to say that NU abandons the modernization of legal thought.
\end{abstract}

Keywords- Ijtihad, Baḥtsul Masāil, Islamic Law.

\section{INTRODUCTION}

In Indonesia, one of the most widely followed community organizations is Nahdlatul Ulama (NU). Since its inception, $\mathrm{NU}$ has been heavily influenced by the struggles of religious thought. NU in fostering Islamic law seems very careful, not even openly returning directly to the Qur'an and Hadith when it faces legal problems that need to be solved. NU scholars (kyai) always return to the opinions of madhab scholars. NU considers the fiqh of the madhab as a final work. In other words, all the legal issues that have been discussed in these works are the essence of the Qur'an and Hadith.[1]
If the establishment of such understanding is seen from Foucault theory, the choice is always oriented to the NU's ulama opinion as a form of power relations and knowledge.[2] Michel Foucault is a French philosopher, historian, intellectual, critic, and sociologist. Foucault is best known for his research on the history of sexuality.[3] His work, which examines power and the relationship between power, knowledge, and discourse, has been widely debated. In the theory he develops, there are two keywords that cannot be separated, namely the 'genealogy' approach and the 'archeological' method. The term genealogy is a term he borrowed from his teacher Nietzsche, while the term 'archaeology' is the result of his thinking.[4]

Regarding these two terms, Foucault explains in his work 'Truth and Power' that; First, truth must be understood as a system of procedures for regulating the production, regulation, distribution, circulation, and operation of statements. Second, 'truth' is always connected and exists in relation to the power system that produces and maintains it. Foucault is always concerned with the effects of power which he influences and propagates. The first hypothesis is Foucault's concise hypothesis about his archaeological method, while the second hypothesis is about his genealogical approach.[5]

This indicates that power is everywhere and arises from relationships between various powers, occurs absolutely, and does not depend on human consciousness. Power is just a strategy. This strategy takes place everywhere and there are systems, rules, arrangements, and regulations. This power does not come from outside, but rather determines the structure, rules, and relationships from within and makes them possible. So, where there is a relation, there is power. This is in accordance with Geoff's opinion, that there are many versions and points of view in formulating Foucault's idea of power, one of which is in the organizational institutions that are scattered in society that affect human life every day.[6] 
In Foucault's theory of power relations and knowledge, when a discourse is born, the discourse has actually been controlled, selected, organized, and redistributed according to the wishes of the maker. The discourse is also constructed based on certain rules (episteme) so that truth has a link with power. This assumption is not without reason, at least in an effort to maintain the transmission chain of Islamic knowledge, $\mathrm{NU}$ is of the opinion that what it is doing is only tracing the good and legitimate links for each generation.

In its operational framework, there are at least three approaches to the study of religion from a Foucauldian perspective:

1. Investigate social practices including religion that will be the target of the investigation. Investigations are directed at practices that are effectively the area of power relations resulting in their repressive effects.

2. Describe how power relations work through the mechanisms provided by these social practices and how these power relations constitute, produce, and generate religious discourse.

3. Analyze how religious discourses that have been produced by power relations further support and justify the operation of these power relations.

So, in the perspective of religious studies, this focuses more on the working of negative power effects, such as limiting, isolating, and repressing an interpretation. With this Foucauldian analysis, the device is not only considered to unite social life or the coercive force that subordinates a group of people to others, but the process that builds the way for all forms of action, social relations, and social order. The study with this approach is a combination of the perspectives of religious studies or cultural studies and critical ones that take sides with values and commitment to changes in the structure of social relations that are hegemonic-dominant.

Due to the wide area of NU followers and the large number of ulama (kyai) involved, it was deemed necessary to institutionalize these fatwas under the NU organization. The institution is known as the Lembaga Bahtsul Masail. As fatwa institutions, the existence of NU and the Lembaga Bahtsul Masail is very strategic for the struggle of Islamic thought in order to answer the problems of Indonesian society. Thus, as a large organization that has a container istinbat law or NU call it Bahtsul Masāil, see this relationship is certainly an interesting thing to study. This problem allows for a power struggle for NU as an institution with knowledge of the broad social realities of the NU community as part of Indonesian society.

With various contemporary religious issues discussed, NU and its Lembaga Bahtsul Masail are required to issue ijtihad, which ultimately gives a decision on a problem that arises, whether to justify, allow, reject, or even blame. Therefore, this paper will explore how NU's ijtihad method in Bahtsul Masāil was analyzed using a genealogical approach and archaeological method developed by Foucault in his theory of power relations and knowledge. After the problems are analyzed, it will be seen how NU's ijtihads in Bahtsul Masāil can give a distinctive color and decorate the pattern of Islamic law in Indonesia.

\section{RESEARCH METHODS}

The writing of this scientific paper uses a qualitative research method with a normative approach.[7] Basically, the study carried out to solve the problem relies on a critical and in-depth study of the relevant library materials, while interviews are only conducted when needed. In other words, qualitative research only describes reality correctly, formed by words based on relevant data obtained from natural situations.[8]

The data source used in this study is a secondary data source because it will only examine the literature or literature.[9] Processing and analyzing data in this study, there are five stages, first, editing, which is to find out how far the data that has been obtained from various sources is good enough and can be immediately prepared for the next process. Second, classifying, namely grouping, where the data from the documentation is classified based on certain categories. Third, verifying, namely as a follow-up step the researcher re-examines the data obtained, for example with the adequacy of references, triangulation (checking through other sources), and peers. Fourth, analyzing, the analysis method that the researcher uses is comparative descriptive, namely collecting, sorting, classifying, synthesizing, and making an overview. Fifth, concluding, as the last step, namely drawing conclusions by analyzing the data comprehensively and connecting the meaning of the existing data in relation to the research problem.[10]

\section{FINDINGS AND DISCUSSION}

In establishing the law, NU seems very cautious and does not want to solve religious issues faced by referring directly or quoting from the texts of the al-Qur'an and Hadith, but tahbiq with the nash in the kitab, if it is not found then ilhāq al-masāil binazhāirihā is in a manner carried out jama'i. The reason is that it cannot be separated from the view that the chain of transferring knowledge of Islam should not be broken from one generation to the next.[11] As for what can be done is to trace the good and legitimate links in each generation. In addition, they realize that it is difficult to do, aware of the limitations to the fulfillment of the requirements to become a mujtahid.

Based on Foucault's theory of power relations, genealogical approaches and archaeological methods are important things to do. The discussion of NU genealogy is 
important and absolutely necessary because it is to understand the characteristics, religious features, and the building of NU's Islamic thought as a whole and accurately. While the archaeological method asserts that truth must be understood as a system of procedures to regulate the production, regulation, distribution, circulation, and operation of statements. Thus, a relation of power and knowledge will be formed with a system that regulates how the production to distribution can work.

This explains that $\mathrm{NU}$ as a power system certainly has certain rules in regulating its production, regulation, distribution, circulation, and operations in establishing law. Regarding NU's prudence, there is at least a historical justification. Ha'iri and Sistani notes that the issue of ijtihad was closed, especially during the time of Imam Haramain, al Juwaini, and al Ghazali was actually not meant as an impossibility of new ijtihad but related to the context of that era, where the freedom of ijtihad turned out to have a wide impact with the emergence of new ijtihad.[12] Various differences in understanding on the scale of complexity, weight, and variety that are increasingly difficult to solve. Scientific ethics for ijtihad is no longer an adequate concern. Everyone seemed free to go on stage to perform ijtihad. This condition turned out to have a negative impact.

The same is true for most of the religious issues discussed and legal decisions made by the Lembaga Bahtsul Masail. This madhab tradition is preserved through pesantren under the auspices of NU. In addition to the question of competence and authority for ijtihad, it is also inseparable from the custom in Pesantren which highly upholds intellectual genealogy in the tradition of taking and practicing a science, it must be clear that the scientific quality of the person being followed. Therefore, such attitudes and views (understanding and interpreting Islamic teachings) by observers often refer to and classify NU in traditional Islamic groups.[13]

With the genealogical approach and archaeological methods, a discourse can be born. With the birth of the discourse, it will be proven how discourse has actually been controlled, selected, organized, and redistributed according to the wishes of its creator, in this case, the NU ulama. Not only that, discourse is also constructed based on certain rules (episteme) so that truth has a link with power. Foucault places the truth of ratio, knowledge, science, academic discourse, and so on in the context of relations with the power which Foucault termed relationships of power and knowledge.

In terms of the relation of power and knowledge in Foucault's perspective, both have a reciprocal relationship. The continuous exercise of power creates an entity of knowledge. Vice versa, the administration of knowledge will have effect of power a very subtle. NU's cultural approach in reducing the values of the al-Qur'an and Hadith in life, encourages Baḥtsul Masāil to be careful when determining laws related to new problems that require fiqh solutions in society.[1] The rule of "maintaining good old values, and adopting new, better values" encourages the Bahtsul Masāil institution to refer to the opinions of their scholars (kyai), and not accept scholars (kyai) other than them in answering various problems that arise in society, of course, by referring to the fiqh of the four schools of thought.[14]

For the NU community, they delegate authority to their ulama as representatives and believe that what is decided is right. So that it can be actualized in life and rely on commitments and agree to the discourses that have been decided by NU scholars in their Bahtsul Masāil.[15] NU believes that they are adherents of Islam as taught by the Prophet Muhammad and practiced by the Companions, who were later called ahl al-sunnah wa aljamá'ah. Islamic teachings have been codified inschools mu'tabarah that Muslims must follow. Each school has its own lineage of scholars which is continued from one generation to the next until now.

Indeed, NU declares and adopts a madhab attitude in understanding and practicing Islamic law, it does not mean that NU is lazy and does not need to ijtihad. What NU wants is that ijtihad can only be done by people who have met the requirements as a mujtahid as stated in Usul Fiqh. For those who meet these requirements, it is better to do ijtihad. On the other hand, for those who do not meet these requirements, it is better to follow the ulama who have the authority to perform ijtihad. This is where NU's caution lies in making laws.[16]

According to Foucault's theory, to see how NU's power relation and its knowledge of ijtihad can be analyzed from three perspectives;[19]

1. There are areas and techniques for regulating power. This technique focuses on how power is exercised as a tactical and strategic game played from countless points. It can come from below, the relationship is imminent, either intentionally or unintentionally.

2. There are governance techniques that link knowledge and power. This is often referred to as disciplinary practice, which is a strategic dimension of power that is manifested as normative maneuver, integration strategies, and productivity tactics. Discipline is a condition when individuals are under certain knowledge domains and are under certain regimes and hierarchies. Discipline is a form of increasing obedience and loyalty to the arrangement and organization of basic reciprocal relationships so that individuals become more sophisticated, rational, and economical because they are always under supervision.

3. The technique of government by connecting self and power. This technique is referred to as 
individualization practice. Foucault exemplifies this practice by explaining the dichotomy of mad and sane, sick and healthy in themselves and from the other.

Of these three components, power arrangements, disciplinary practices, and individualization practices in terms of understanding NU based on Foucault's theory, ijtihad is only carried out by people who meet the requirements as mujtahid, while people who have deep religious knowledge but do not meet the requirements of mujtahid, it is better to taqlid to scholars who have the ability to ijtihad because they have fulfilled the requirements. This does not mean that NU does not want ijtihad. For NU, taqlid does not only mean following the opinions of others without understanding the arguments but also following the way of thinking of the Imam of the school of thought in exploring the law.[17]

Looking at the historical background and attitude, NU actually really considers the negative aspects if ijtihad is opened openly. NU's rigidity in viewing ijtihad is based on the quality needs of a person to perform ijtihad. NU maintains that the differences that arise do not widen due to uncontrolled ijtihad. It is these things that underlie NU's emphasis on the use of the method of analyzing religious issues by referring to the method developed by the previous Imam Madhab.[18] Because until now this method is considered the most mu'tabar and no new original method has emerged.

From the perspective of religious traditions, the discourses created and constructed by NU have persuasive authority so that they become an alternative/guideline for the NU community as readers in order to construct their attitudes and behavior. So, in resolving a problem, Lembaga Bahtsul Masail does not use the term ijtihad which is believed to be only feasible for the mujtahid earlier, but uses the term istinbat legal madhāby approach. This means that scholars who are members of the Lembaga Bahtsul Masail solve religious problems faced by NU residents by being oriented to the schools of fiqh which are limited to the fiqh of four schools.

In applying the approach mazhāby, Lembaga Bahtsul Masail used three kinds of methods istinbat law applied in stages. The method istinbat law applied by the Lembaga Bahtsul Masail NU is:[14]

\section{The method Qauly}

Qauly means opinion, the method Qauly is a legal istimbath method used by NU ulama/intellectuals in the Lembaga Bahtsul Masail by studying the problems at hand, then looking for answers in fiqh books from the four schools of thought, by referring and referring directly to the sound of the text. It means a way of establishing law by referring to the mu'tabarah pole of the priests mazāhib. Or in other words, follow the opinions that already exist within the scope of a particular school. This concept is proven by the fact that almost all decisions made by the Lembaga Bahtsul Masail must include the opinion of a madhab priest.

2. The method Ilhaqy

Ilhaqy means analogy, the method Ilhaqy is equating the law of a case/problem that has not been answered by the book (there is no legal determination) with a similar case/problem that has been answered by the book (there has been a legal determination) or equating it with an existing opinion. In contrast to qiyas, where one of the elements of al-ashl is from the al-Qur'an and Sunnah, ilhaqy is defined as an analogical process with al-ashl which is the opinion of the priests of the school of thought. An example is the Bahtsul Masāil decision issued at the Second Congress (Surabaya, 9-11 October 1927) regarding the legality of buying and selling firecrackers. This is based on the analogy of buying and selling allowed in the kitab I'anah al-Talibin juz III p. 121-122, alBajury p. 652-654, al-Jamal ala fathi al-Wahhab juz III p. 24 on the basis of equality of cause, namely to please people and get good.

3. The method Manhajiy

Manhajiy means methodological, the method Manhajiy is a way of solving religious problems taken by the Lembaga Bahtsul Masail by following the way of thinking and the rules of law that have been compiled by the priest of the school. He stipulates the law by taking illah the inform of the realization of a benefit to the law. As with the qauliy and ilhaqiy, in methods fact the method manhajiy has also been applied by previous NU scholars, although not with the term manhajiy and nor formalized through a decision.

The orientation of ijtihad that pays attention to the fiqh opinions of previous scholars suggests that Bahtsul Masaìl did not have the courage to carry out ijtihad as the absolute Imam Mujtahid did. This view is based on the fact that it is difficult to find scholars who meet the requirements to be able to perform ijtihad. Moreover, to become a mujtahid, some useful scholars provide quite strict requirements. Some of these requirements, among others, as explained by Imam an-Nawawi in al-Kitab alMajmu quotes Abu Amr who mentions that the absolute mujtahid requirements are: a) understanding the arguments of shariah law derived from the al-Qur'an, hadith, ijma', qiyas in depth and detail, b) having knowledge of the conditions for the validity of the arguments and understanding the indications of those arguments, so that they can draw legal conclusions based on those arguments (mastering the science of ushul fiqh), c) being able to master the science of fiqh and its branches, d) mastering the sciences of the al-Qur'an, the sciences of hadith, nasikh and mansukh, arabic, nahwu, sharaf, differences and consensus of scholars, with careful and deep mastery.[12] 
However, in fact, the orientation of this NU style of fiqh is a reflection of the basics of NU society which are included in the following universal values: a) Tawāsut and I'tidal, namely a middle and straight attitude that has the core principle of life that upholds the necessity of being fair and straight in society. in the midst of life together, and avoid all forms of approaches that are tatarruf (extreme). b) Tasamuh, namely tolerant attitude towards different views, both in religious matters (especially regarding furu'/branches or khilafiyah issues/disputed), social and cultural matters. c) Tawazun, which is a balanced attitude in serving, both to Allah, which is associated with social life, to humans, and to the environment. Align the interests of the past, present and future. d) Amar ma'ruf nahi munkar, namely always having the sensitivity to encourage good and beneficial actions for life together, as well as reject and prevent things that can plunge and demean the values of life.

\section{CONCLUSION}

Due to the vast territory of NU followers and a large number of kiyai involved, it was deemed necessary to institute fatwa under the NU organization. The institution is known as the Lembaga Bahtsul Masail. The Lembaga Bahtsul Masail NU cannot be separated from the tradition of fiqh thought from the four schools of thought, namely Hanafi, Maliki, Shafi'i, and Hambali. This is in accordance with Foucault's theory of power relations, with the genealogical approach and archaeological methods, a discourse can be born. With the birth of this discourse, it revealed how discourse has actually been controlled, selected, organized, and redistributed according to the wishes of its creator, in the case of NU scholars. This can also be seen from the attitude of NU in establishing the law. NU seems very careful and does not want to solve the religious problems it faces by referring directly to or quoting from the Qur'an and Hadith texts but also uses the ability of reason coupled with empirical reality. The relationship between Bahtsul Masāil power and NU citizens as objects of power is reflected in solving a problem, the Lembaga Bahtsul Masail does not use the term ijtihad which is believed to be only appropriate for previous mujtahid scholars but uses the term istinbat legal with approach madhaby. This means that scholars who are members of the Lembaga Bahtsul Masail solve religious problems faced by NU residents by projecting to the schools of fiqh which are mostly associated, but not limited, to the four schools of thoughts.

\section{REFERENCES}

[1] 'Hasil-Hasil Muktamar Ke-33 Nahdhatul Ulama'. Lembaga Ta'lif Wan Nasyr PBNU Jakarta, 2016.

[2] B. E. Harcourt, 'Five Modalities of Michel Foucault's Use of Nietzsche's Writings (1959-73): Critical, Epistemological, Linguistic, Alethurgic and Political', no. Special Issue: Foucault Before the Colle'ge de France, pp. 1-22, 2021, doi: $10.1177 / 0263276421994916$.
[3] S. Elden, Review: Michel Foucault, Histoire de la sexualité 4: Les aveux de la chair. Paris: Gallimard, 2018.

[4] M. Hoffman, 'Book Review: La société punitive: Cours au Collège de France, 1972-1973', vol. 43, no. 4, pp. 553-557, 2015, doi: 10.1177/0090591715589951.

[5] M. Bowdridge and S. Blenkinsop, 'Michel Foucault Goes Outside: Discipline and Control in the Practice of Outdoor Education', Journal of Experiential Education, vol. 34, no. 2, pp. 149-163, 2011, doi: 10.5193/JEE34.2.149.

[6] I. Sudrajat, 'Foucault, the Other Spaces, and Human Behaviour', Procedia - Social and Behavioral Sciences 3, vol. 36, pp. 28-34, 2012.

[7] C. O. Sendil and N. O. Kucukertan, 'A qualitative study about transmission of religious issues', Procedia - Social and Behavioral Sciences, vol. 47, pp. 913-917, 2012, doi: 10.1016/j.sbspro.2012.06.756.

[8] H. Nassaji, 'Good qualitative research', Language Teaching Research, vol. 24, no. 2, pp. 427-431, 2020, doi: $10.1177 / 1362168820941288$.

[9] A. M. Epp and C. C. Otnes, 'High-Quality Qualitative Research: Getting Into Gear', Journal of Service Research, vol. 24, no. 2, pp. 163-167, 2021, doi: 10.1177/1094670520961445.

[10] M. Decuypere, 'Visual Network Analysis: R a qualitative method for researching sociomaterial practice', Qualitative Research, vol. 20, no. 1, pp. 73-90, 2020, doi: 10.1177/1468794118816613.

[11] R. Jackson, 'Islam, Democracy and the Spiritual Path. Transformation: An International Journal of Holistic Mission Studies', vol. 30, no. 2, pp. 107-116, 2013, doi: $10.1177 / 0265378813476794$.

[12] R. Gleave, 'Conceptions of Authority in Iraqi Shi'ism Baqir alHakim, Ha'iri and Sistani on Ijtihad, Taqlid and Marja'iyya', vol. 24, no. 2, pp. 59-78, 2007, doi: 10.1177/0263276407074996.

[13] I. S. Wekke, 'Technology on Language Teaching and Learning: A Research on Indonesian Pesantren', Procedia - Social and Behavioral Sciences, vol. 83, pp. 585-589, 2013, doi: 10.1016/j.sbspro.2013.06.111.

[14] A. Wasik, 'Optimalisasi Nalar Kritis Santri Dalam Sistem Bahtsul Masa'il Fiqhiyah NU', Jurnal Lisan al-Hal, vol. 6, no. 2, Desember 2014, [Online]. Available: journal.kopertais4.or.id/index.php/lisan/article/download/1187/82 3

[15] T. J. D'Agostino, 'What's faith got to do with it? A scoping study on local faith communities supporting child development and learning', International Journal of Educational Development, vol. 81, 2021, doi: https://doi.org/10.1016/j.ijedudev.2020.102325.

[16] E. Moosa and A. A. Mian, Islam. Durham: Duke University, 2012 .

[17] L. Salaymeh, Islamic Law. Berkeley: University of California (UC) Berkeley School of Law, 2015.

[18] A. K. Willard, A. F. Shariff, and A. Norenzayan, 'Religious Priming as a research tool for studying religion: Evidentiary Value, Current Issues, and Future Directions', Department of Psychology University of Texas, 2016, doi: 10.1016/j.copsyc.2016.06.003.

[19] D. Ladkin and J. Probert, 'From sovereign to subject: Applying Foucault's conceptualization of power to leading and studying power within leadership', The Leadership Quarterly, 2019, doi: 10.1016/j.leaqua.2019.10131. 